Original Article

\title{
Second world record for two Calvatia species (Agaricaceae: Basidiomycota)
}

\author{
Segundo registro mundial para duas espécies de Calvatia (Agaricaceae: Basidiomycota)
}

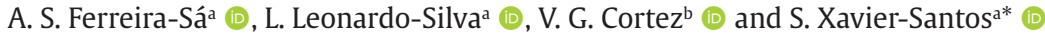 \\ aUniversidade Estadual de Goiás - UEG, Laboratório de Micologia Básica, Aplicada e Divulgação Científica - FungiLab, Anápolis, GO, Brasil \\ bUniversidade Federal do Paraná - UFPR, Departamento de Biodiversidade, Palotina, PR, Brasil
}

\begin{abstract}
Calvatia is a genus of gasteroid fungi, comprising about 47 species worldwide. In this paper we report the second worldwide occurrence of two poorly known species of Calvatia, recorded in the Cerrado biome of Brazil: C. oblongispora and C. nodulata. Detailed morphological descriptions and illustrations, including scanning electron micrographs of hyphae and basidiospores are provided, as well a discussion on their taxonomy and geographic distribution.

Keywords: Brazilian Cerrado, gasteroid fungi, Gasteromycetes, puffballs, fungal taxonomy.

Resumo

Calvatia é um gênero de fungos gasteroides que compreende cerca de 47 espécies em todo o mundo. Neste artigo relatamos a segunda ocorrência de duas espécies pouco conhecidas de Calvatia, registradas no bioma Cerrado do Brasil: C. oblongispora e C. nodulata. Descrições morfológicas detalhadas e ilustrações são fornecidas, incluindo micrografias eletrônicas de varredura de hifas e basidiósporos, bem como uma discussão sobre sua taxonomia e distribuição geográfica.
\end{abstract}

Palavras-chave: Cerrado brasileiro, fungos gasteroides, Gasteromicetos, bola da terra, taxonomia fúngica.

\section{Introduction}

The genus Calvatia Fr. (Agaricaceae: Basidiomycota) was proposed in 1849 by Fries, whose representatives are popularly known as puffballs. They are characterized by the globose to pyriform basidioma, gleba pulverulent or cottony, dehiscence by irregular ruptures in the peridium, and not by apical pore (Miller and Miller, 1988; Baseia, 2003).

Currently, around 47 species are accepted for the genus (Kirk et al., 2008; Suarez et al., 2009; Alves and Cortez, 2013; Rebriev, 2013; Alfredo et al., 2014; Crous et al., 2018; Gunasekaran et al., 2018; Crous et al., 2019), where 13 of them occur in Brazil, specifically in the North, Northeast, South and Southeast regions, with most reports for the Atlantic Forest. The Central-Western region of Brazil has no record of the genus.

Studies have contributed to increase the knowledge about the distribution and description of new species of the genus in Brazil, such as Baseia (2003), Baseia and Calonge (2008), Cortez et al. (2012), Cortez and Alves (2012), Alves and Cortez (2013), and Crous et al. (2018). This study reports the occurrence of two species of Calvatia in the
Brazilian Cerrado, improving the mycological knowledge of this important Brazilian biome.

\section{Material and Methods}

Basidiomata were collected between 2008 and 2018 during the rainy season, in three locations in the Brazilian Cerrado: I) the Parque Estadual da Serra dos Pirineus (PEP) (15 $\left.80^{\prime} 47^{\prime \prime} \mathrm{S}, 48^{\circ} 84^{\prime} 46^{\prime \prime} \mathrm{W}\right)$, in the municipality of Pirenópolis; II) the Reserva Ecológica da Universidade Estadual de Goiás (REC-UEG) (16³8’41” S, 489'46” W), municipality of Anápolis, both in the state of Goiás; and III) Jardim Botânico de Brasília (JBB) (1551'43” S, 47²9'49” W), in Brasília, Federal District (Figure 1).

The material identification was based on macro- and micromorphological characterization of the basidioma, following the criteria used by Miller and Miller (1988) and the descriptions of Suárez et al. (2009) and Alfredo et al. (2014). Samples were photo-documented through a light microscope (LM) OLYMPUS CX31 and a scanning electron microscope (SEM) HITACHI (TM3030PLUS). The color

*e-mail: solange.xavier@ueg.br

Received: January 22, 2021 - Accepted: March 8, 2021 


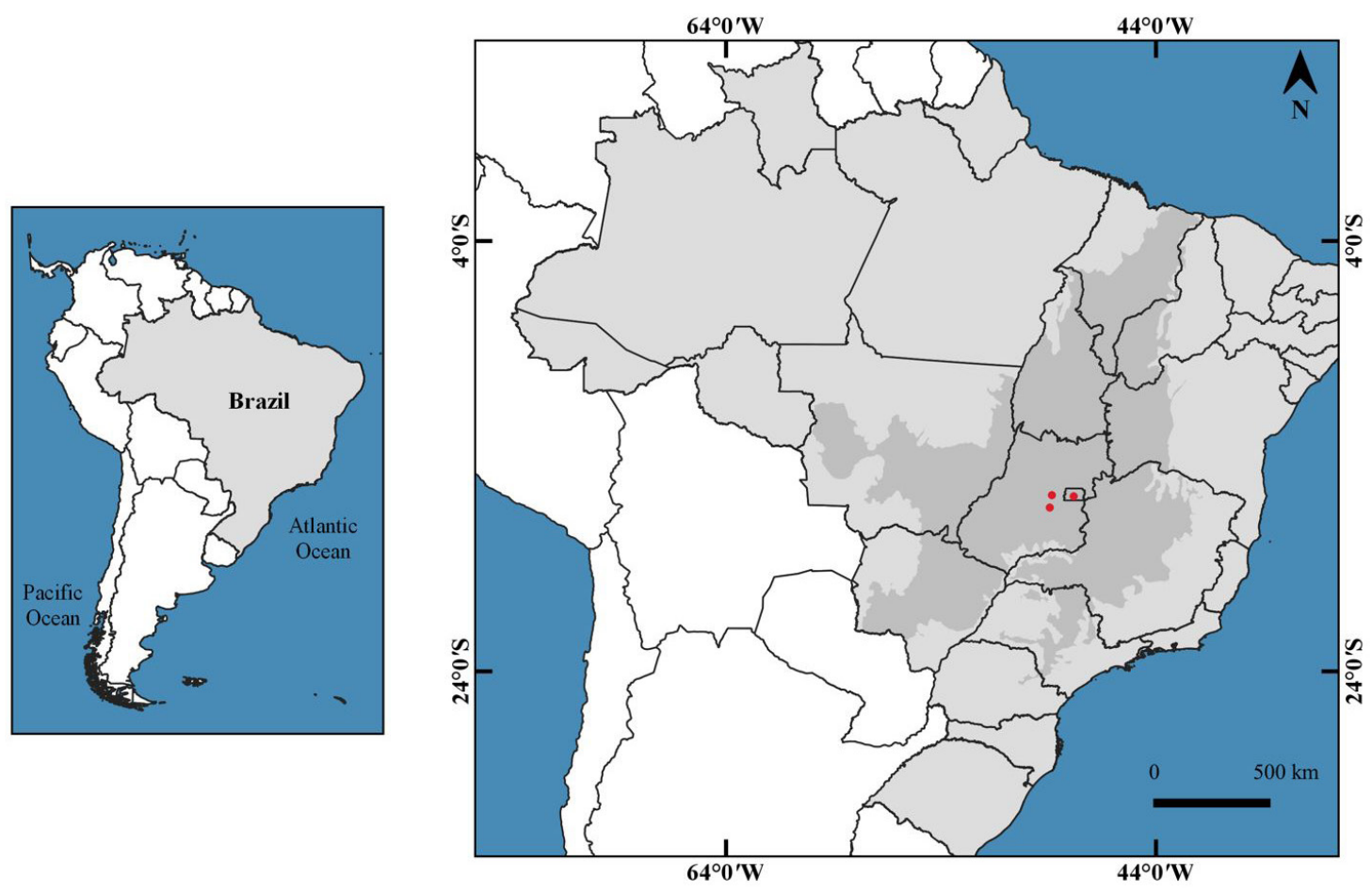

Figure 1. Location of the study area and sampling localities (red dots) in the Biome Cerrado (dark gray) in the Brazilian territory (light gray).

classification was based on Kornerup and Wanscher (1978). The specimens were deposited in the Herbarium of the Universidade Estadual de Goiás, Anápolis, Brazil (HUEG).

\section{Results}

\subsection{Taxonomy}

\subsubsection{Calvatia oblongispora V.L. Suárez, J.E. Wright E F. Calonge (2009: 324) (Figure 2)}

Mature basidiomata globose to subglobose, $8-11 \mathrm{~cm}$ in diameter, yellowish white (1A2) when fresh, greyish yellow (4B3) when dry. Peridium papyraceous, slightly wrinkled, with few cracks at the apex, when fresh and crumbling when dry, formed by two-layered: an outer one, composed of hyaline hyphae, branched, without pores and intertwined, and an inner one pseudoparenchymatous layer. Mature gleba light brown (7E7) when dry, with a pulverulent aspect. Capillitium fragile, with walls measuring 0.24-0.81 $\mu \mathrm{m}$ in thickness and 1.11-3.83 $\mu \mathrm{m}$ in diam.; septa and pores with $1.0-1.92 \mu \mathrm{m}$ in diam. Basidiospores elliptical, 5.63-7.55 × 3.05-4.30 $\mu \mathrm{m}$, hyaline in LM; ornamented with spines arranged in longitudinal rows.

Known distribution: Only known from type locality, Northern Brazil, state of Amazonas (Suárez et al., 2009).

Material examined: BRAZIL, Goiás, Pirenópolis, Parque Estadual da Serra dos Pirineus, 12 Nov 2008, leg. S. Xavier-Santos (3359), (HUEG12059); Ibid, SXS3412 (HUEG12060); Anápolis, Reserva Ecológica da
Universidade Estadual de Goiás (REC-UEG), 28 Feb 2018, leg. S. Xavier-Santos, SXS6299 (HUEG12061).

Additional material examined: BRAZIL, Manaus, Amazonas, 4 Feb 1978, leg. Singer, B10605 (INPA82826 holotype).

Comments: Distinctive characteristics that differentiate C. oblongispora from the other species of the genus are the presence of large pores that extend throughout the capillitium, exoperidium with two layers, an outer with interwoven, septate and branched hyphae, and an inner pseudoparenchymatous layer, and elliptical basidiospores with a distinct spiny ornamentation, with spines arranged in ridges along the basidiospore wall (Suárez et al., 2009). We perform all the recommended methods for the herborization of the specimens, however, it was not enough to preserve some characteristics such as the differences between gleba and subgleba, but according to the original description, the gleba is cottony, with yellowish central region, and the subgleba is prominent, concolor to the central portion of the gleba. The specimens of $C$. oblongispora examined were collected in forest formations in the Cerrado, during the rainy season.

\subsubsection{Calvatia nodulata D.S. Alfredo E I.G. Baseia (2014) (Figure 3)}

Basidioma pyriform, $3.5-5.5 \mathrm{~cm}$ in width, $8.2 \mathrm{~cm}$ in height; exoperidium yellowish brown (5F7) when mature, sandy aspect in the apical surface, endoperidium. Gleba brownish grey (5C2), non-pulverulent, occupying the apex of basidioma, totally exposed when mature; subgleba cottony, dark brown (6F5), occupying half of 

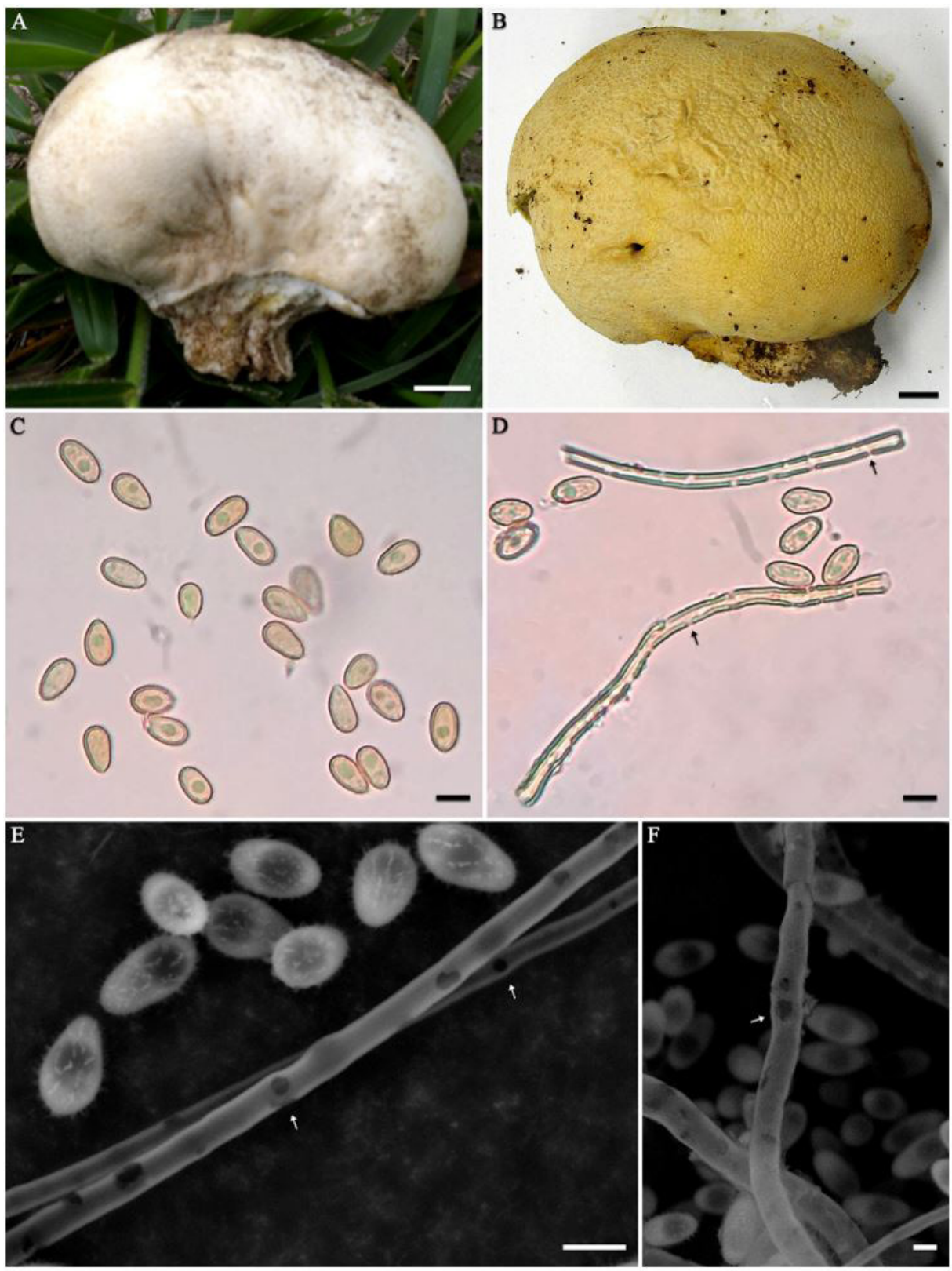

Figure 2. Calvatia oblongispora. (A) (SXS3359) and (B) (SXS6299): fresh basidiomata; (C) and (D) Basidiospores and capillitium with pores evidenced by arrows; (E) and (F) Basidiospores and capillitium with pores evidenced by arrows through scanning electron microscopy. A, B - Bars $=1 \mathrm{~cm} ; \mathrm{C}-\mathrm{F}=4 \mu \mathrm{m}$.

the basidioma. Endoperidium papyraceous, smooth to slightly wrinkled surface, light brown (5D5) to dark blond (5D4). Capillitium sparingly branched, septate, walls $1.57-2.57 \mu \mathrm{m}$ in diam., $0.21-0.51 \mu \mathrm{m}$ in thickness, with nodes of $0.78-1.11 \mu \mathrm{m}$ in height, arranged irregularly throughout the capillitium. Basidiospores globose to subglobose, 3.07-3.52 × 3.09-3.54 $\mu \mathrm{m}$, with spiny ornamentation, subtly interconnected by endosporic projections at the base of spines, forming grooves.

Known distribution: Only known from Northeastern Brazil, states of Ceará and Paraíba (Alfredo et al., 2014).
Material examined: BRAZIL, Federal District, Brasília, Jardim Botânico de Brasília, 01 Dec 2010, leg. S. Xavier-Santos, SXS7009, (HUEG12982).

Comments: The distinctive features that differentiate it from the other species of the Calvatia are the presence of nodes in the capillitium, that can be spaced from each other, not having regular arrangement; exoperidium not persistent, likely absent when mature; disappearance of the subgleba, that results in cracks inside the mature basidioma; besides the dark coloration of the gleba and spiny ornamentation of the basidiospores, which are 
A

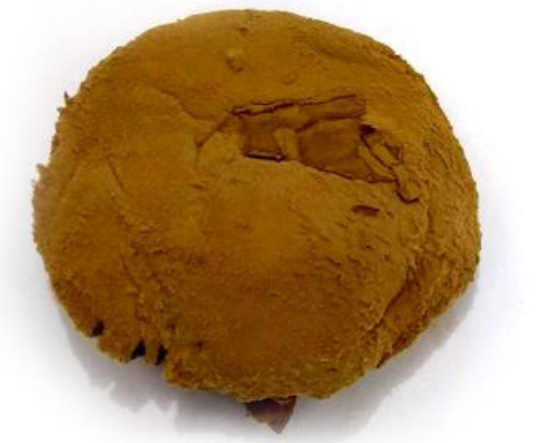

B

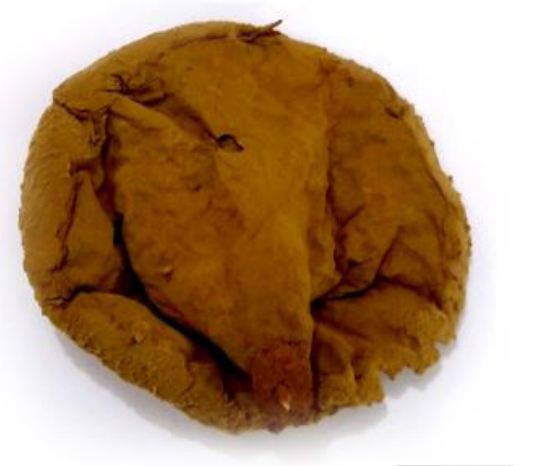

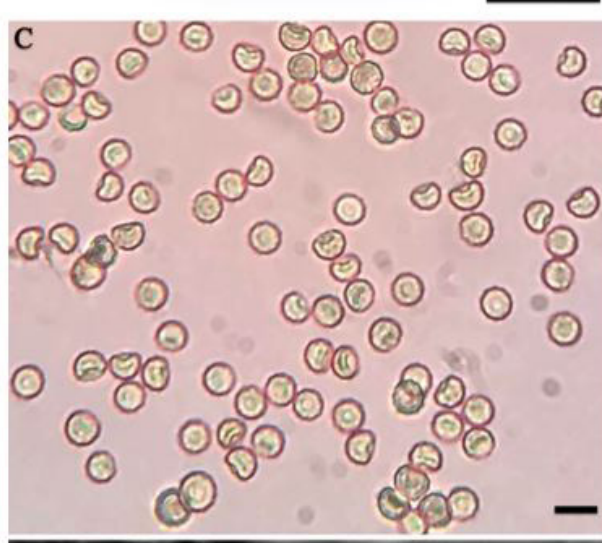
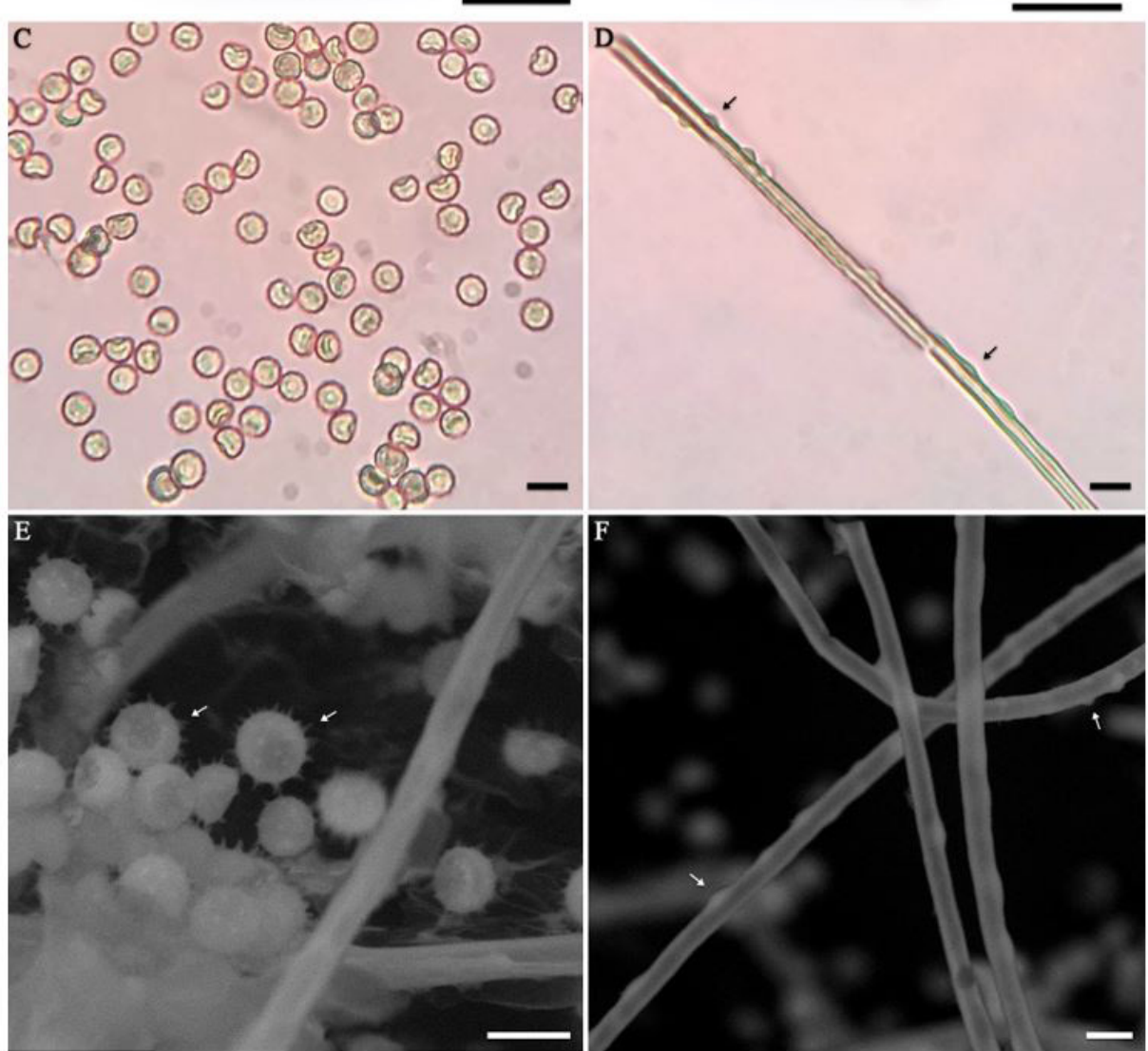

Figure 3. Calvatia nodulata. (A) and (B) dry basidioma (SXS7009); (C) basidiospores in light microscope; (D) capillitium with nodes evidenced by arrows; (E) basidiospore ornamentation in scanning electron microscopy evidenced by arrows; (F) capillitium in scanning electron microscopy with nodes evidenced by arrows. A, B - Bars $=2 \mathrm{~cm}$; C-F $=4 \mu \mathrm{m}$.

also important characteristics to identify this species (Alfredo et al., 2014).

\section{Discussion}

Calvatia oblongispora was described in 2009 based on material collected by Rolf Singer in 1978, in the Amazon, and deposited in the Herbarium of the Instituto Nacional de Pesquisas da Amazônia (INPA) in Manaus, Amazonas, Brazil (Suárez et al., 2009). Calvatia nodulata was described in 2014 (Alfredo et al., 2014) from samples collected in three Brazilian states of Ceará, Paraíba, and Rio Grande do Norte, both in the Northeast region. Since then, there have been no new reports of these species' occurrences in other regions of Brazil or the world.

The morphological characteristics observed in the studied specimens coincide with those found in the protologue descriptions of both species. Due to the remarkable characteristics of these species, differentiation through phenotypic comparison can be used. Calvatia guzmanii C.R. Alves \& Cortez is a species that also 
shows the capillitium with abundant pores but differs from $C$. oblongispora because it shows the exoperidium completely spinose, with pyramidal spines tightly grouped and basidiospores globose, ornamented with short and sharp spines. Calvatia caatinguensis R.L. Oliveira, R.J. Ferreira, B.D.B. Silva, M.P. et al. (Crous et al., 2018) is another species similar to C. oblongispora, however, it has subglobose basidiospores, color variation at the apex of the subgleba and one-layered exoperidium.

Suárez et al. (2009) indicated similarities between C. oblongispora and C. sporocristata Calonge, described from Costa Rica (Calonge et al., 2003). Calvatia sporocristata also shows elliptical basidiospores with spines arranged in ridges, however, it differs from $C$. sporocristata because it has only one pseudoparenchymatous layer in the exoperidium and capillitium without pores. Calonge et al. (2003) and Suárez et al. (2009) also proposed to place both species (C. oblongispora and C. sporocristata) in a new Section Sporocristata Calonge, due to the similarity between the spore ornamentation of the two species, since the species from Calvatia section proposed by Kreisel (1994), have no such ornamentation. A thrid species within the Sect. Sporocristata has been described from Vietnam, C. holothurioides Rebriev (Rebriev, 2013). This species is characterized by the pyriform basidioma and the outer layer of the exoperidium formed by hyphal-vesiculose structures, different from C. oblongispora, which has globose to subglobous basidioma and the outer layer of the exoperidium formed by filamentous hyphae.

Calvatia nodulata differs from all above cited species because the capillitium present numerous nodules along and, when mature, more than half of the basidioma is filled with a cottony subgleba, which has several cavities, besides the dehiscence through the complete release of the exoperidium, exposing the entire gleba. It differs from C. oblongispora, whose dehiscence is due to irregular ruptures of exoperidium, which is not completely detached from the basidioma.

The present study increases the knowledge of the geographic distribution of $C$. oblongispora and $C$. nodulata, establishing second world records, the first record of these species for the Cerrado biome, and of the genus in Central-Western region of Brazil.

\section{Acknowledgements}

To the Coordenação de Aperfeiçoamento de Pessoal de Nível Superior (CAPES), for Master's scholarship provided to A.S. Ferreira-Sá (88887.483339/2020-00) and Ph.D. scholarship provided to L. Leonardo-Silva (88882.448042/2019-01). To the reviewers and editors for valuable comments and editorial preparation of the paper.

\section{References}

ALFREDO, D.D.S., RODRIGUES, A.C.M. and BASEIA, I.G., 2014. Calvatia nodulata, a new gasteroid fungus from Brazilian semiarid region. Journal of Mycology, vol. 2014, pp. 1-7. http://dx.doi. org/10.1155/2014/697602.
ALVES, C.R. and CORTEZ, V.G., 2013. Calvatia guzmanii sp. nov. (Agaricaceae, Basidiomycota) from Paraná State, Brazil. Phytotaxa, vol. 85, no. 2, pp. 35-40. http://dx.doi.org/10.11646/ phytotaxa.85.2.1.

BASEIA, I.G., 2003. Contribution to the study of the genus Calvatia (Lycoperdaceae) in Brazil. Mycotaxon, vol. 88, pp. 107-112.

BASEIA, I.G. and CALONGE, F.D., 2008. Calvatia sculpta, a striking puffball occurring on Brazilian sand dunes. Mycotaxon, vol. 106, pp. 269-272.

CALONGE, F.D., MATA, M. and CARRANZA, J., 2003. Calvatia sporocristata sp. nov. (Gasteromycetes) from Costa Rica. Revista de Biología Tropical, vol. 51, no. 1, pp. 79-83. PMid:15162683.

CORTEZ, V.G. and ALVES, C.R., 2012. Type study of Calvatia lachnoderma from Brazil. Mycosphere, vol. 3, no. 6, pp. 894-898. http://dx.doi.org/10.5943/mycosphere/3/6/3.

CORTEZ, V.G., BASEIA, I.G. and SILVEIRA, R.M.B., 2012. Gasteroid mycobiota of Rio Grande do Sul, Brazil: Calvatia, Gastropila and Langermannia (Lycoperdaceae). Kew Bulletin, vol. 67, no. 3, pp. 471-482. http://dx.doi.org/10.1007/s12225-012-9364-6.

CROUS, P.W., WINGFIELD, M.J., BURGESS, T.I., HARDY, G.E.S.J., GENÉ, J., GUARRO, J., BASEIA, I.G., GARCÍA, D., GUSMÃO, L.F.P., SOUZA-MOTTA, C.M., THANGAVEL, R., ADAMČÍK, S., BARILI, A., BARNES, C.W., BEZERRA, J.D.P., BORDALLO, J.J., CANOLIRA, J.F., OLIVEIRA, R.J.V., ERCOLE, E., HUBKA, V., ITURRIETAGONZÁLEZ, I., KUBÁTOVÁ, A., MARTÍN, M.P., MOREAU, P.A., MORTE, A., ORDOÑEZ, M.E., RODRÍGUEZ, A., STCHIGEL, A.M., VIZZINI, A., ABDOLLAHZADEH, J., ABREU, V.P., ADAMČÍKOVÁ, K., ALBUQUERQUE, G.M.R., ALEXANDROVA, A.V., ÁlVAREZ DUARTE, E., ARMSTRONG-CHO, C., BANNIZA, S., BARBOSA, R.N., BELLANGER, J.M., BEZERRA, J.L., CABRAL, T.S., CABOŇ, M., CAICEDO, E., CANTILLO, T., CARNEGIE, A.J., CARMO, L.T., CASTAÑEDA-RUIZ, R.F., CLEMENT, C.R., ČMOKOVÁ, A., CONCEIÇÃO, L.B., CRUZ, R.H.S.F., DAMM, U., SILVA, B.D.B., SILVA, G.A., SILVA, R.M.F., DE A SANTIAGO, A.L.C.M., DE OLIVEIRA, L.F., DE SOUZA, C.A.F., DÉNIEL, F., DIMA, B., DONG, G., EDWARDS, J., FÉLIX, C.R., FOURNIER, J., GIBERTONI, T.B., HOSAKA, K., ITURRIAGA, T., JADAN, M., JANY, J.L., JURJEVIĆ, Ž., KOLAŘíK, M., KUŠAN, I., LANDELL, M.F., LEITE CORDEIRO, T.R., LIMA, D.X., LOIZIDES, M., LUO, S., MACHADO, A.R., MADRID, H., MAGALHÃES, O.M.C., MARINHO, P., MATOČEC, N., MEŠIĆ, A., MILLER, A.N., MOROZOVA, O.V., NEVES, R.P., NONAKA, K., NOVÁKOVÁ, A., OBERLIES, N.H., OLIVEIRA-FILHO, J.R.C., OLIVEIRA, T.G.L., PAPP, V., PEREIRA, O.L., PERRONE, G., PETERSON, S.W., PHAM, T.H.G., RAJA, H.A., RAUDABAUGH, D.B., ŘEHULKA, J., RODRÍGUEZ-ANDRADE, E., SABA, M., SCHAUFLEROVÁ, A., SHIVAS, R.G., SIMONINI, G., SIQUEIRA, J.P.Z., SOUSA, J.O., STAJSIC, V., SVETASHEVA, T., TAN, Y.P., TKALČEC, Z., ULLAH, S., VALENTE, P., VALENZUELA-LOPEZ, N., ABRINBANA, M., VIANA MARQUES, D.A., WONG, P.T.W., XAVIER DE LIMA, V. and GROENEWALD, J.Z., 2018. Calvatia caatinguensis. Fungal planet desprition sheets. Persoonia, vol. 4, pp. 326-327. http://dx.doi.org/10.3767/persoonia.2018.40.10. PMid:30505003.

CROUS, P.W., CARNEGIE, A.J., WINGFIELD, M.J., SHARMA, R., MUGHINI, G., NOORDELOOS, M.E., SANTINI, A., SHOUCHE, Y.S., BEZERRA, J.D.P., DIMA, B., GUARNACCIA, V., IMREFI, I., JURJEVIĆ, Ž., KNAPP, D.G., KOVÁCS, G.M., MAGISTÀ, D., PERRONE, G., RÄMÄ, T., REBRIEV, Y.A., SHIVAS, R.G., SINGH, S.M., SOUZA-MOTTA, C.M., THANGAVEL, R., ADHAPURE, N.N., ALEXANDROVA, A.V., ALFENAS, A.C., ALFENAS, R.F., ALVARADO, P., ALVES, A.L., ANDRADE, D.A., ANDRADE, J.P., BARBOSA, R.N., BARILI, A., BARNES, C.W., BASEIA, I.G., BELLANGER, J.M., BERLANAS, C., BESSETTE, A.E., BESSETTE, A.R., BIKETOVA, A.Y., BOMFIM, F.S., BRANDRUD, T.E., BRANSGROVE, K., BRITO, A.C.Q., CANO-LIRA, J.F., CANTILLO, T., CAVALCANTI, A.D., CHEEWANGKOON, R., CHIKOWSKI, R.S., CONFORTO, C., CORDEIRO, T.R.L., CRAINE, 
J.D., CRUZ, R., DAMM, U., DE OLIVEIRA, R.J.V., DE SOUZA, J.T., DE SOUZA, H.G., DEARNALEY, J.D.W., DIMITROV, R.A., DOVANA, F., ERHARD, A., ESTEVE-RAVENTÓS, F., FÉLIX, C.R., FERISIN, G., FERNANDES, R.A., FERREIRA, R.J., FERRO, L.O., FIGUEIREDO, C.N., FRANK, J.L., FREIRE, K.T.L.S., GARCÍA, D., GENÉ, J., GÊSIORSKA, A., GIBERTONI, T.B., GONDRA, R.A.G., GOULIAMOVA, D.E., GRAMAJE, D., GUARD, F., GUSMÃO, L.F.P., HAITOOK, S., HIROOKA, Y., HOUBRAKEN, J., HUBKA, V., INAMDAR, A., ITURRIAGA, T., ITURRIETA-GONZÁLEZ, I., JADAN, M., JIANG, N., JUSTO, A., KACHALKIN, A.V., KAPITONOV, V.I., KARADELEV, M., KARAKEHIAN, J., KASUYA, T., KAUTMANOVÁ, I., KRUSE, J., KUŠAN, I., KUZNETSOVA, T.A., LANDELL, M.F., LARSSON, K.H., LEE, H.B., LIMA, D.X., LIRA, C.R.S., MACHADO, A.R., MADRID, H., MAGALHÃES, O.M.C., MAJEROVA, H., MALYSHEVA, E.F., MAPPERSON, R.R., MARBACH, P.A.S., MARTÍN, M.P., MARTÍNSANZ, A., MATOČEC, N., MCTAGGART, A.R., MELLO, J.F., MELO, R.F.R., MEŠIĆ, A., MICHEREFF, S.J., MILLER, A.N., MINOSHIMA, A., MOLINERO-RUIZ, L., MOROZOVA, O.V., MOSOH, D., NABE, M., NAIK, R., NARA, K., NASCIMENTO, S.S., NEVES, R.P., OLARIAGA, I., OLIVEIRA, R.L., OLIVEIRA, T.G.L., ONO, T., ORDOÑEZ, M.E., OTTONI, A.M., PAIVA, L.M., PANCORBO, F., PANT, B., PAWŁOWSKA, J., PETERSON, S.W., RAUDABAUGH, D.B., RODRÍGUEZ-ANDRADE, E., RUBIO, E., RUSEVSKA, K., SANTIAGO, A.L.C.M.A., SANTOS, A.C.S., SANTOS, C., SAZANOVA, N.A., SHAH, S., SHARMA, J., SILVA, B.D.B., SIQUIER, J.L., SONAWANE, M.S., STCHIGEL, A.M., SVETASHEVA, T., TAMAKEAW, N., TELLERIA, M.T., TIAGO, P.V., TIAN, C.M., TKALČEC, Z., TOMASHEVSKAYA, M.A., TRUONG,
H.H., VECHERSKII, M.V., VISAGIE, C.M., VIZZINI, A., YILMAZ, N., ZMITROVICH, I.V., ZVYAGINA, E.A., BOEKHOUT, T., KEHLET, T., LÆSSØE, T. and GROENEWALD, J.Z., 2019. Calvatia brasiliensis: fungal planet description sheets. Persoonia, vol. 43, pp. 394-395. http://dx.doi.org/10.3767/persoonia.2019.42.11. PMid:31551622.

GUNASEKARAN, S., CHINNARAJAN, R. and PARASNIS, A., 2018. Notes on Indian species of Calvatia and Langermannia including Calvatia natarajanii sp. nov. Phytotaxa, vol. 362, no. 2, pp. 160172. http://dx.doi.org/10.11646/phytotaxa.362.2.3.

KIRK, P.M., CANNON, P.F., MINTER, D.W. and STALPERS, J.A., 2008. Dictionary of the Fungi. 10nd ed. Wallingford: CABI, $771 \mathrm{p}$.

KORNERUP, A. and WANSCHER, J.H., 1978. Methuen handbook of colours. 3rd ed. London: Eyre Methuen, 252 p.

KREISEL, H., 1994. Studies in the Calvatia complex (Basidiomycetes). Feddes Repertorium, vol. 105, no. 5-6, pp. 369-376. http://dx.doi. org/10.1002/fedr.19941050516.

MILLER, O.K. and MILLER, H.H., 1988. Gasteromycetes: morphology and developmental features. Eureka, CA: Mad River Press, $157 \mathrm{p}$.

REBRIEV, Y.A., 2013. Calvatia holothurioides sp. nov. from Vietnam. Mikologiâ i Fitopatologiâ, vol. 47, pp. 21-23.

SUÁREZ, V.L., WRIGHT, J.E. and CALONGE, F.D., 2009. Calvatia oblongispora sp. nov. from Brazil, with close affinities to $C$. sporocristata from Costa Rica. Mycotaxon, vol. 108, no. 1, pp. 323-327. http://dx.doi.org/10.5248/108.323. 